\title{
PERANCANGAN E-BOARD SEBAGAI ALAT DISTRIBUSI INFORMASI PADA SISTEM KERJA SAMA ASINKRON TERSEBAR
}

\author{
Agustinna Yosanny; Yen Lina Prasetio; Irwan Lasiman; Welly \\ Jurusan Teknik Informatika, Fakultas Ilmu Komputer, Bina Nusantara University \\ Jln. K.H. Syahdan No.9, Palmerah, Jakarta Barat 11480 \\ ayosanny@binus.edu
}

\begin{abstract}
The design of e-Board was undertaken to meet the necessary of information between colleagues that nowadays has become more essential and vital especially in a team work that applying distributed asynchronous co-operative work system. In which, members of the team are distributed in time and space; therefore information should be well distributed to support the cooperative work between them. The research was applying analysis and design methodology. The analysis methodology was undertaken through literature study, current system observation, questionnaire survey to users to identify characteristics of the current and entailed information distribution media. The design methodology was undertaken through database, features, system, and screen layout design. Results of the research found that the information distribution media for team work which has applied distributed asynchronous co-operative work system should have the ability of private access for each member, better organization in information categorizing, structured information for task assignment, and supporting member's mobility. In conclusion, the application has been expected to help task assignment, distribution and organization of information in the distributed asynchronous co-operative work system to be easier and simpler.
\end{abstract}

Keyword: e-Board, web, distributed asynchronous

\begin{abstract}
ABSTRAK
Perancangan e-Board dilakukan untuk menjawab kebutuhan akan informasi yang dirasakan semakin penting dan mendesak terutama pada sistem kerja sama asinkron tersebar dimana personilnya berada pada tempat dan waktu yang berbeda sehingga informasi perlu didistribusikan dengan baik untuk mendukung kerjasama pada kelompok tersebut. Metodologi yang digunakan adalah metode analisis dan perancangan. Langkah-langkah pada metode analisis yaitu studi literatur, survei sistem yang sudah berjalan, kuisioner untuk mengetahui karakteristik media-media distribusi informasi, dan analisis terhadap kuisioner dan mengidentifikasi kebutuhan informasi. Sedangkan langkah-langkah pada metode perancangan yaitu perancangan fitur, perancangan UML, dan perancangan layar. Hasil yang didapat adalah sebuah aplikasi yang memiliki kemampuan seperti private access, pengorganisasian informasi yang lebih baik, informasi yang lebih terstruktur untuk membantu proses penugasan dan dapat mendukung mobilitas individu yang berbeda-beda. Jadi aplikasi e-Board diharapkan dapat membantu distribusi informasi, organisasi informasi, dan penugasan pada sistem kerja sama asinkron tersebar.
\end{abstract}

Kata kunci: e-Board, web, asinkron tersebar 


\section{PENDAHULUAN}

\section{Latar Belakang}

Dengan semakin banyaknya informasi yang beredar di berbagai komunitas, khususnya di lingkungan kelompok kerja saat ini, kebutuhan akan informasi dirasakan semakin penting dan mendesak. Suatu informasi mungkin dibutuhkan oleh satu individu saja dalam suatu kelompok kerja, tetapi informasi yang sama juga mungkin dibutuhkan oleh beberapa orang individu dalam suatu kelompok kerja tertentu untuk mendukung kerjasama dalam kelompok tersebut. Dewasa ini, mobilitas individu dalam perkerjaan semakin meningkat. Untuk itu akses dan distribusi informasi harus dapat dilakukan oleh setiap individu yang membutuhkan informasi dari tempat dan waktu yang berbeda, sehingga kelancaran kerja tetap terjaga.

Selain pendistribusian informasi ke setiap individu dalam kelompok kerja, pengorganisasian informasi, terutama untuk kepentingan masing-masing individu, seperti penjadwalan kerja, pelaksanaan tugas dan sebagainya, juga perlu dikoordinasikan dan diorganisasikan dengan baik. Sehingga akan membantu setiap individu dalam melaksanakan setiap tugas yang menjadi tanggung jawabnya dengan lebih baik dan terorganisasi.

\section{Tinjauan Pustaka}

\section{Computer-Supported Cooperative Work (CSCW)}

Menurut Shneiderman (2010), definisi CSCW adalah bidang studi yang berfokus pada perancangan dan evaluasi teknologi baru untuk mendukung proses sosial kerja, sering di antara mitra yang berjauhan. Hasil CSCW biasanya disebut Groupware. Matriks waktu-ruang untuk mengelompokkan sistem kerja sama seperti pada Gambar 1.

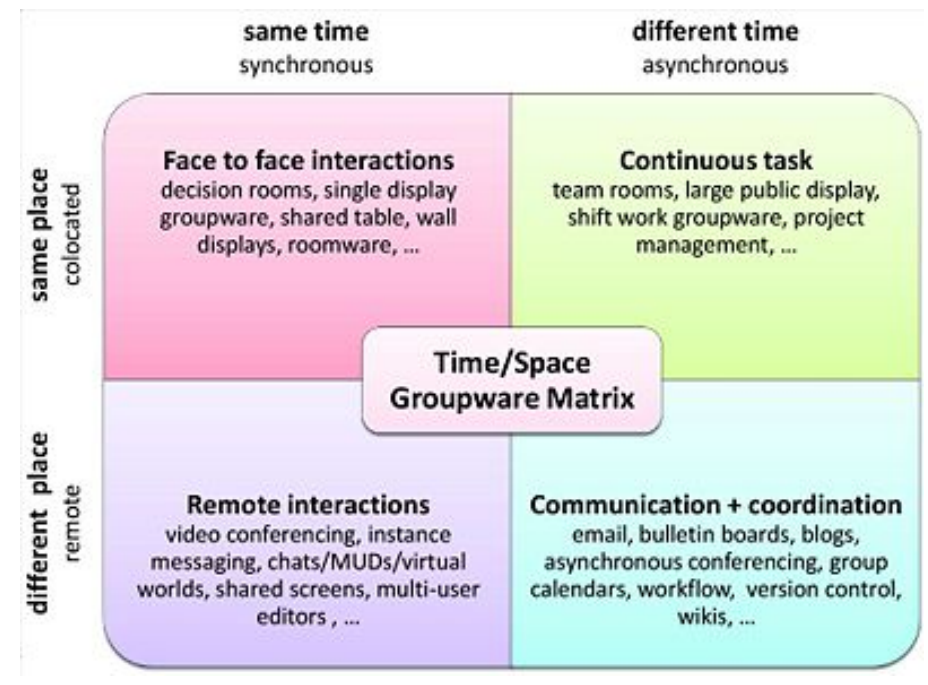

Gambar 1 Matriks ruang waktu pengelompokan sistem kerja sama

\section{Groupware}

Groupware adalah jenis software yang membantu kelompok kerja (workgroup) yang terhubung ke jaringan untuk mengelola aktivitas mereka. Menurut Messerchmitt (2000), ada lima hal yang menjadi titik berat dalam penggunaan groupware yaitu (1) priority, pendistribusian informasi 
sebaiknya diberi level prioritas sehingga penerima informasi dapat mendahulukan yang lebih penting; (2) filtering, tanpa adanya filtering pada informasi yang masuk maka akan mengakibatkan waktu terbuang untuk beberapa informasi yang sebenarnya tidak penting, identitas pengirim dan subyek/isi dari informasi dapat dijadikan salah satu kriteria penyaringan; (3) autentification, untuk menanggulangi adanya seseorang yang memberikan informasi dengan menggunakan identitas palsu dibutuhkan autentifikasi identitas pengirim; (4) integrity, dalam proses distribusinya, informasi mungkin mendapat penambahan ataupun penggurangan isi. untuk itu, pesan dengan integrity dibutuhkan agar informasi yang diterima sama dengan apa yang dikirim; (5) confidentiality, beberapa informasi mungkin berisi hal-hal yang sensitif yang hanya boleh sampai pada pihak yang bersangkutan, confidentiality dibutuhkan untuk mencegah terjadinya kebocoran informasi tersebut.

\section{Web 2.0}

Web 2.0, adalah sebuah istilah yang dicetuskan pertama kali oleh O'Reilly pada tahun 2003, dan dipopulerkan pada konferensi Web 2.0 pertama di tahun 2004, merujuk pada generasi yang dirasakan sebagai generasi kedua layanan berbasis web - seperti situs jaringan sosial, wiki, perangkat komunikasi, dan folksonomi-yang menekankan pada kolaborasi online dan berbagi antar pengguna. Menurut O'Reilly, Web 2.0 adalah sebuah revolusi bisnis di dalam industri komputer yang terjadi akibat pergerakan ke internet sebagai platform, dan suatu usaha untuk mengerti aturan-aturan agar sukses di platform tersebut. Walaupun kelihatannya istilah ini menunjukkan versi baru daripada web, istilah ini tidak mengacu kepada pembaruan kepada spesifikasi teknis World Wide Web, tetapi lebih kepada bagaimana cara pengembang sistem di dalam menggunakan platform web.

\section{AJAX}

Konsep AJAX diperkenalkan oleh Jesse James Garret (2005) dari tim adaptive path dengan mengeluarkan esai yang dipublikasikan di adaptive path dengan kode esai bernomor 00385. Sebelum AJAX diperkenalkan, aplikasi web kurang populer karena memiliki tingkat responsif yang rendah dibanding aplikasi desktop yang memiliki tingkat responsif tinggi. Hal ini juga mengurangi pengalaman pengguna dalam menggunakan aplikasi.

Perbedaan tersebut kini dapat diatasi dengan adanya AJAX, yang telat diterapkan dalam beberapa aplikasi yang dapat dengan gampang kita temui seperti Google Suggest atau Google Maps, kita hanya perlu menggunakan scroll mouse kita untuk zoom secara instant tanpa harus reload. AJAX merupakan singkatan dari Asynchronous JavaScript and XML. AJAX merupakan gabungan dari beberapa bagian teknologi yang memiliki fungsinya masing-masing.

AJAX merupakan gabungan dari presentasi berdasarkan standar dengan XHTML (eXtensible Hypertext Mark-up Language) dan CSS (Cascading Style Sheet), tampilan dan interaksi yang dinamis dengan document object model, pertukaran dan manipulasi data dengan XML dan XSLT, pengambilan data secara asynchronous dengan menggunakan XMLHttpRequest, dan semuanya digabung menjadi satu kesatuan aplikasi dengan JavaScript. Aplikasi web klasik mengambil semua data yang diperlukan user dan nantinya ditampilkan ketika user member request dan hal ini membuat user menunggu beberapa saat setelah aplikasi dijalankan.

\section{METODE}

Metode yang digunakan dalam penelitian ini meliputi empat tahapan. Pertama adalah analisa kebutuhan user. Pada tahap ini dilakukan survei terhadap sistem yang berjalan dan studi literatur. Kedua adalah metode perancangan. Dari hasil analisa kebutuhan user, dibuat perancangan aplikasi 
sebagai alat distribusi informasi pada komunitas kerja. Dalam proses perancangan aplikasi dilakukan perancangan-perancangan seperti perancangan fitur, perancangan sistem, perancangan database dan perancangan layar sebagai storyboard dari aplikasi yang diusulkan. Ketiga adalah metode implementasi. Implementasi dilakukan selama 2-3 bulan dan akan terus di-maintain untuk mendapatkan feedback dan perbaikan bug yang mungkin muncul saat implementasi. Pada tahap ini dilakukan implementasi aplikasi yang dibuat kepada komunitas kerja user yang telah dilakukan survei sebelumnya. Keempat adalah tahap evaluasi. Pada tahap ini dilakukan evaluasi terhadap semua fiturfitur yang ada dan antar muka pemakai dalam aplikasi ini supaya mendapatkan hasil yang memuaskan dan aplikasi dapat digunakan.

\section{HASIL DAN PEMBAHASAN}

\section{Identifikasi Masalah}

Cara pendistribusian informasi dapat dilakukan dengan berbagai cara, yaitu dengan menggunakan media non-elektronik ataupun media elektronik. Contoh penggunaan media nonelektronik adalah pendistribusian informasi dengan menggunakan whiteboard atau secara oral. Kedua cara ini memiliki beberapa kelebihan, seperti mudah digunakan (tidak memerlukan waktu belajar), murah dan cepat sehingga cara tersebut masih banyak digunakan. Kekurangan media non-elektronik adalah dalam hal pengaksesan informasi dan keamanan informasi.

Untuk mengatasi kekurangan yang disebutkan diatas, maka banyak orang mulai beralih ke media elektronik untuk pendistribusian informasi, dimana media ini memungkinkan private access, dapat menjaga integritas informasi dan mendukung mobilitas individu yang tinggi. Contoh media elektronik yang menjadi pilihan utama untuk mendukung kerjasama tim dalam suatu kelompok saat ini adalah aplikasi e-mail. Aplikasi ini memungkinkan untuk private access sehingga kerahasiaan dan integrasi informasi tetap dapat terjaga diantara anggota tim kerja, penambahan dan pengurangan isi informasi yang didistribusikan dapat diminimalisasi serta mendukung mobilitas individu. Selain itu terdapat pula kekurangan dari penggunaan e-mail tersebut, yaitu dalam hal pendistribusian maupun pengorganisasian informasi oleh masing-masing individu kerja seperti pengirim informasi harus mengetahui alamat e-mail dari penerima informasi dan proses filtering masih harus dilakukan oleh individu sendiri.

Selain beberapa kekurangan media non-elektronik dan elektronik yang telah disebutkan di atas, terdapat kekurangan lain pada kedua media tersebut yaitu informasi yang didistribusikan bersifat tidak terstruktur. Hal ini tentu akan menyulitkan dalam proses penugasan kepada individu lain karena membutuhkan usaha yang lebih untuk membuat detil informasi yang akan didistribusikan.

Melihat kekurangan yang dimiliki oleh beberapa media yang umum digunakan dalam pendistribusian informasi saat ini, oleh karena itu dibutuhkan suatu sistem distribusi informasi yang memiliki kemampuan-kemampuan untuk menutupi kekurangan dari media yang ada sekarang ini, seperti private access, pengorganisasian informasi yang lebih baik, informasi yang lebih terstruktur sehingga dapat mengakomodasi kebutuhan informasi dari suatu kelompok kerja, dan dapat digunakan pada tingkat mobilitas individu yang berbeda-beda. Dimana hal ini diharapkan untuk dapat mendukung kerjasama dalam kelompok kerja tersebut.

\section{Gambaran Umum}

Aplikasi E-Board (Gambar 2) merupakan aplikasi pendistribusian dan pengorganisasian informasi yang digunakan pada komunitas kerja yang tidak berada pada satu ruangan yang sama. 


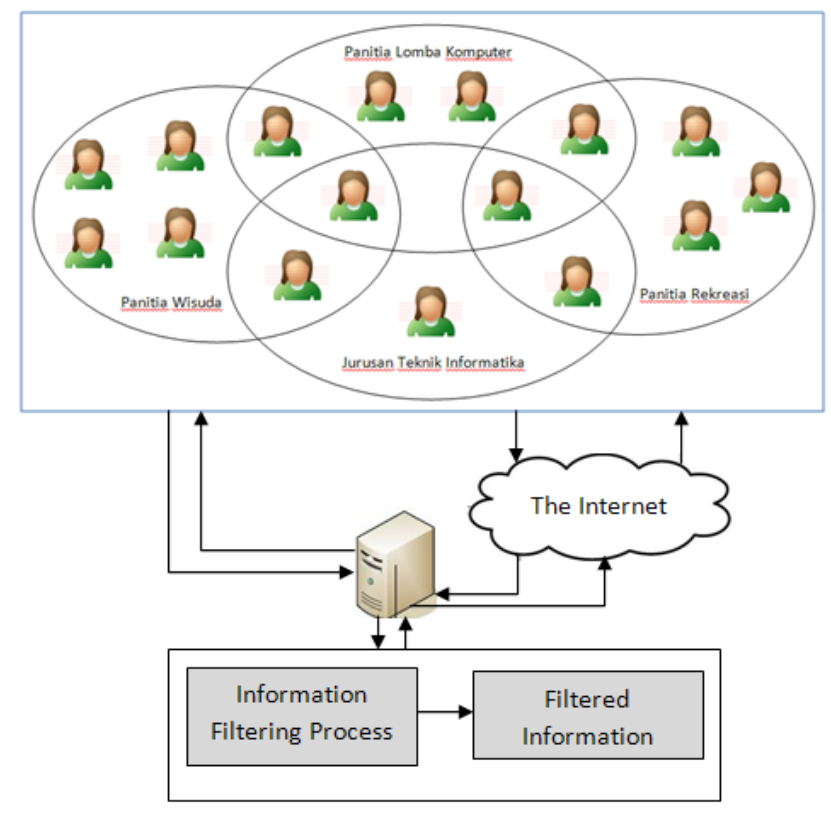

Gambar 2 Rancangan sistem aplikasi e-board

Adapun fitur-fitur yang ada dalam aplikasi tersebut antara lain: (1) grup, yaitu setiap user akan dikelompokan ke dalam grup-grup komunitas kerja yang dimilikinya. Pengelompokan awal didasarkan pada komunitas kerja (bagian) masing-masing user bekerja. Namun tidak menutup kemungkinan untuk membuat grup komunitas kerja yang beranggotakan user yang berasal dari berbagai bagian, tetapi memiliki kepentingan untuk berkolaborasi dalam suatu kelompok kerja fungsional lainnya, misalnya dalam suatu kepanitiaan. Informasi yang diterima user akan dikelompokan berdasarkan grup sehingga mempermudah dalam pencarian informasi yang dibutuhkan; (2) pengumuman, yaitu fitur yang digunakan untuk mendistribusikan informasi secara broadcasting. Pengumuman tersebut dapat langsung ditanggapi oleh rekan kerja yang lain dengan menggunakan fitur Comment. Selain itu, terdapat kalender yang digunakan untuk membantu mengingat tanggaltanggal acara.

(3) Status, yaitu fitur untuk memberitahukan keberadaan dirinya ataupun keberadaan rekan kerja lainnya dalam setiap komunitas kerja yang dimilikinya. Dengan adanya fitur ini diharapkan dapat mempermudah mengetahui keberadaan rekan kerja terutama yang tidak berada pada satu ruangan; (4) Fitur penugasan, di mana rekan kerja dapat memberikan tugas kepada rekan kerja dengan mengisi sebuah form. Form tersebut sudah terstruktur dan memiliki detil informasi yang lengkap. Proses penugasan dianggap selesai apabila rekan kerja sudah mengisi laporan. (5) To-do list, yaitu fitur untuk membantu user dalam mengatur pekerjaannya; (6) pemberian prioritas pada setiap informasi sehingga user dapat menentukan apa yang harus dikerjakan terlebih dahulu; (7) pembuatan aplikasi berbasiskan Web 2.0 yang menggunakan teknologi AJAX bertujuan agar mendukung mobilitas user dalam bekerja. Penggunaan teknologi AJAX pada aplikasi ini dengan pertimbangan bahwa tingkat kepadatan lalu lintas data antara server dan client dapat diminimalisasi sehingga relatif lebih cepat, user dapat berinteraksi dengan data dan mengontrol data tersebut, ketentuan yang tetap sehingga user tidak akan menemukan model interaksi baru yang memungkinkan user merasa tidak familiar dengan model tersebut, mudah diakses karena internet yang menjadi platform sehingga tidak tergantung kepada OS. 


\section{Perancangan}

\section{Perancangan Fitur}

Fitur-fitur yang ada pada aplikasi disusun menjadi: (1) login; (2) fitur user, yaitu memilih grup, menampilkan status, membuat pengumuman, membuat penugasan dan pelaporan, mendistribusikan pesan; (3) fitur admin, menambahkan dan mengurangi user serta menambahkan dan mengurangi grup; dan (4) logout.

\section{Perancangan Sistem}

\section{Use Case Diagram}

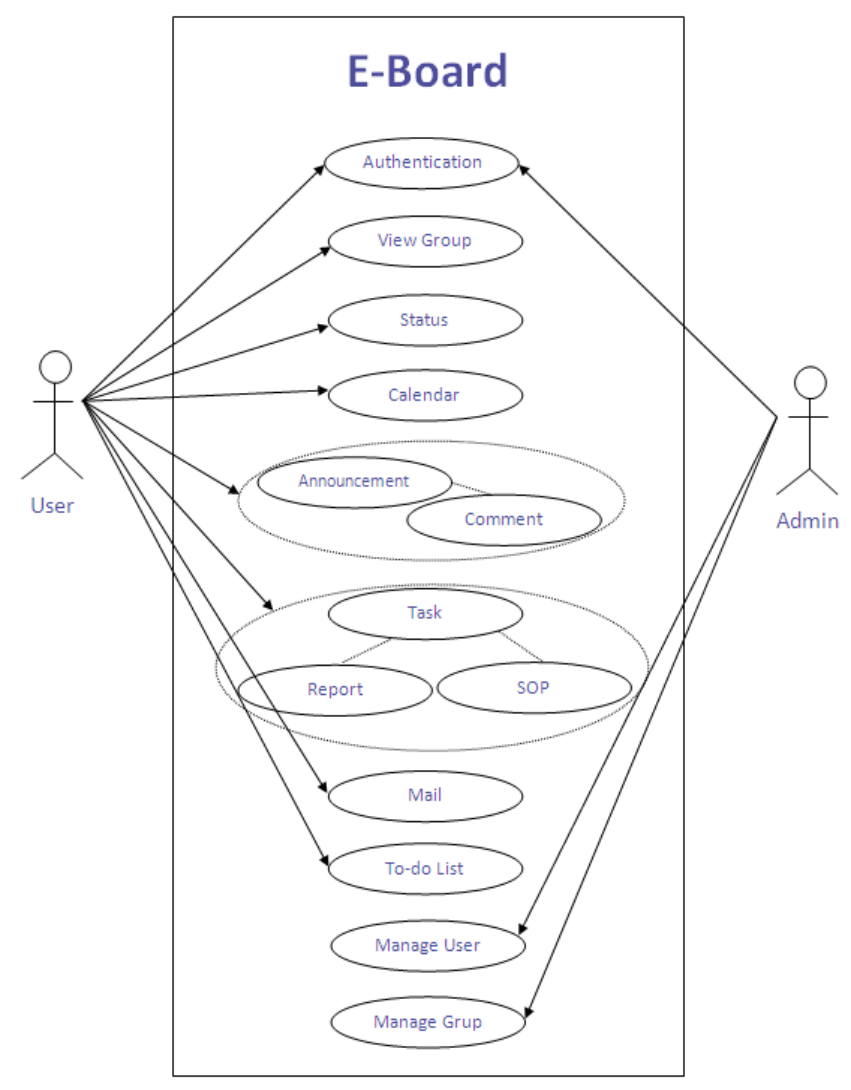

Gambar 3 Diagram use case aplikasi e-board

Dalam rancangan use case diagram pada Gambar 3, diperlihatkan semua fitur yang terdapat pada sistem yang akan dibuat dengan aktor-aktor yang memiliki hak untuk melakukan akses terhadap fitur-fitur yang ada. Pada use case diagram dapat dilihat bahwa aplikasi ini memiliki 2 jenis user yaitu user dan admin. User memiliki akses pada fitur-fitur authentication, view group, status, calendar, announcement beserta comment, task beserta report dan sop, mail, dan to-do list. Sedangkan admin dapat mengakses fitur-fitur authentication, manage user dan manage grup.

Pada fitur authentication terdapat dua fungsi yaitu fungsi login dan logout untuk autentikasi user sebelum masuk ke dalam aplikasi. Dengan demikian akses terhadap informasi bisa dibatasi hanya untuk user yang berhak terhadap informasi tersebut. Fungsi login juga menjadi kunci untuk menentukan grup komunitas kerja yang dimiliki oleh setiap user. Dengan demikian informasi yang disampaikan setiap user akan diorganisasi pada saat user melakukan login. 
Setelah login, pada halaman awal aplikasi ini, user dapat memilih komunitas kerja yang ingin ditampilkan informasinya melalui fungsi view group. Fungsi sini digunakan oleh user untuk berpindah-pindah komunitas kerja yang dimilikinya untuk melihat informasi yang diterima sesuai dengan komunitas kerja yang sesuai. Dengan demikian user akan lebih mudah mencari informasi yang dibutuhkan untuk suatu komunitas kerja tertentu. Dengan pengelompokan komunitas kerja ini juga diharapkan dapat meminimalkan kesalahan pengiriman yang mungkin terjadi dengan penggunaan media yang sebelumnya.

Fungsi Status digunakan user untuk menyampaikan status keberadaannya, dan dapat dilihat oleh semua user yang berada dalam satu komunitas kerja yang sama. Selain untuk menuliskan status user sendiri, user juga dapat menuliskan status untuk user lain dalam komunitas kerjanya yang diketahuinya. Fungsi Calendar membantu user sebagai reminder untuk kegiatan-kegiatan tertentu yang telah didistribusikan atau dibuat melalui aplikasi ini. Fungsi ini juga akan ditampilkan sesuai komunitas kerja yang sedang diaktifkan.

Fungsi Announcement merupakan salah satu fungsi distribusi informasi yang memiliki struktur informasi berupa pengumuman. Melalui fungsi ini, diharapkan user dapat mendistribusikan informasi yang bersifat broadcasting pada satu komunitas kerja tertentu yang diinginkan. Dengan demikian user tidak perlu lagi memilih rekan kerja yang akan menerima informasi ini, dimana memungkinkan terjadinya kesalahan pengiriman, karena otomotasi oleh server informasi ini akan didistribusikan ke semua rekan kerja dalam komunitas kerja yang dipilih. Pada fungsi ini user penerima informasi juga bisa menuliskan komentar sebagai respon terhadap pengumuman yang disampaikan. Dengan demikian respon dari suatu informasi akan lebih terorganisasi dan tidak tersebar, sehingga akan lebih mudah ditemukan jika dibutuhkan nantinya.

Fungsi Task merupakan fungsi distribusi informasi yang juga memiliki struktur informasi tertentu. Pada fungsi ini, user dapat memberikan penugasan kerja terhadap rekan kerja yang berada dalam satu komunitas kerja dengan mengisi formulir yang telah disediakan. Sehingga user tidak perlu lagi membuat struktur penugasan sendiri yang mana akan lebih menghemat waktu bagi si pemberi tugas. Pada fungsi ini terdapat juga fungsi untuk pembuatan SOP yang nantinya akan ditampilkan sebagai detil penugasan. Dengan menggunakan SOP, maka penugasan terhadap suatu tugas sudah mempunyai kerangka kerja dan prosedur tertentu yang konsisten. Selain pembuatan SOP, fungsi ini juga dilengkapi dengan fungsi pelaporan jika tugas yang ditugaskan sudah selesai dikerjakan. Pemberi tugas juga dapat melihat dan memonitor pekerjaan rekan kerja yang diberi tugas melalui fungsi ini dan melihat laporan yang disampaikan untuk setiap penugasan kerja.

Fungsi berikutnya adalah Mail, merupakan fungsi untuk mengirimkan pesan-pesan pendek kepada satu atau lebih rekan kerja. Dengan demikian masih ada informasi selain pengumuman, penugasan, dan pelaporan yang bisa didistribusikan melalui aplikasi ini. Fungsi ini memiliki fungsi yang sama dengan media $e$-mail yang sudah ada, namun dengan memanfaatkan fungsi ini institusi akan dapat lebih menghemat kapasitas e-mail dan bandwidth internet daripada menggunakan e-mail.

Fungsi terakhir adalah To-do List, dimana merupakan suatu fungsi tambahan yang bisa digunakan oleh user untuk membuat daftar pekerjaan untuk tiap-tiap komunitas kerja, sehingga daftar pekerjaan yang harus dilakukan tidak tercampur antar satu komunitas kerja dengan yang lainnya. Pada fungsi ini juga akan ditampilkan reminder ke user untuk setiap daftar kerja yang sudah mencapai batas waktu pengerjaannya. Berikut adalah gambar use case diagram untuk perancangan aplikasi secara keseluruhan.

\section{Class diagram}

Class diagram menggambarkan rancangan obyek-obyek yang akan digunakan dalam aplikasi yang diusulkan. Selain menggambarkan obyek-obyek yang akan digunakan, pada diagram ini juga 
digambarkan hubungan dan relasi antar obyek. Dengan demikian akan lebih mudah untuk merancang penyimpanan data untuk aplikasi yang diusulkan. Gambar 4 adalah gambar class diagram untuk aplikasi yang diusulkan.

\section{Perancangan Database}

Dari hasil perancangan obyek yang akan digunakan pada aplikasi ini, maka didapatkan rancangan penyimpanan data yang akan digunakan untuk menyimpan informasi dari setiap obyek yang digunakan pada aplikasi ini. Pada rancangan penyimpanan data ini juga digambarkan relasi antar table untuk memperlihatkan relasi data yang digambarkan dalam Entity Relationship Diagram pada Gambar 5.

\section{Implementasi dan Evaluasi}

\section{Spesifikasi Sistem}

Aplikasi E-Board menggunakan perangkat keras dan perangkat lunak baik untuk server maupun client. Untuk server, spesifikasi perangkat keras yang digunakan adalah processor minimum Pentium 4, memori minimum 512 MB, harddisk dengan space minimum $20 \mathrm{~GB}$, ethernet card, mouse, keyboard, dan monitor.

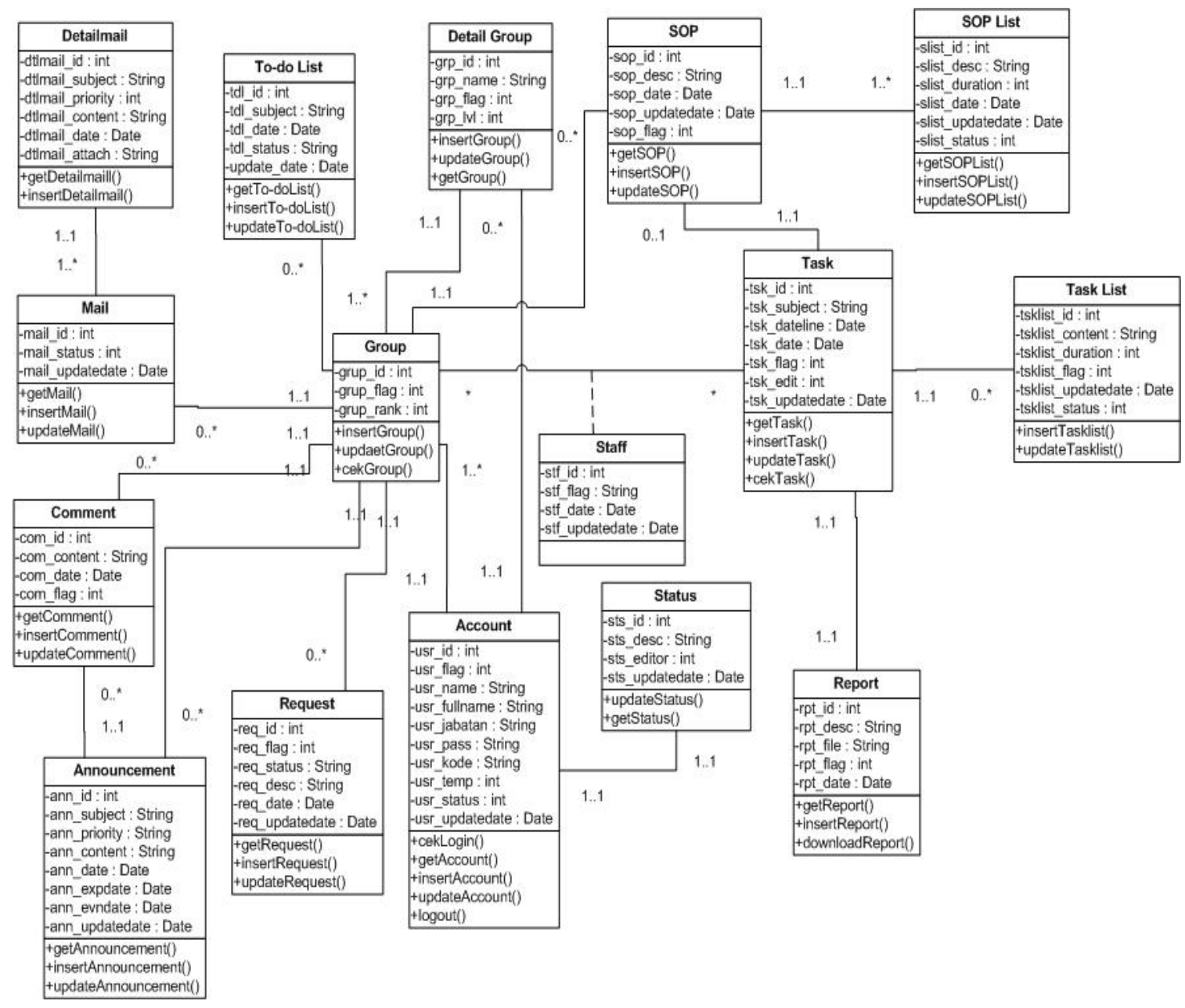

Gambar 4 Class Diagram 


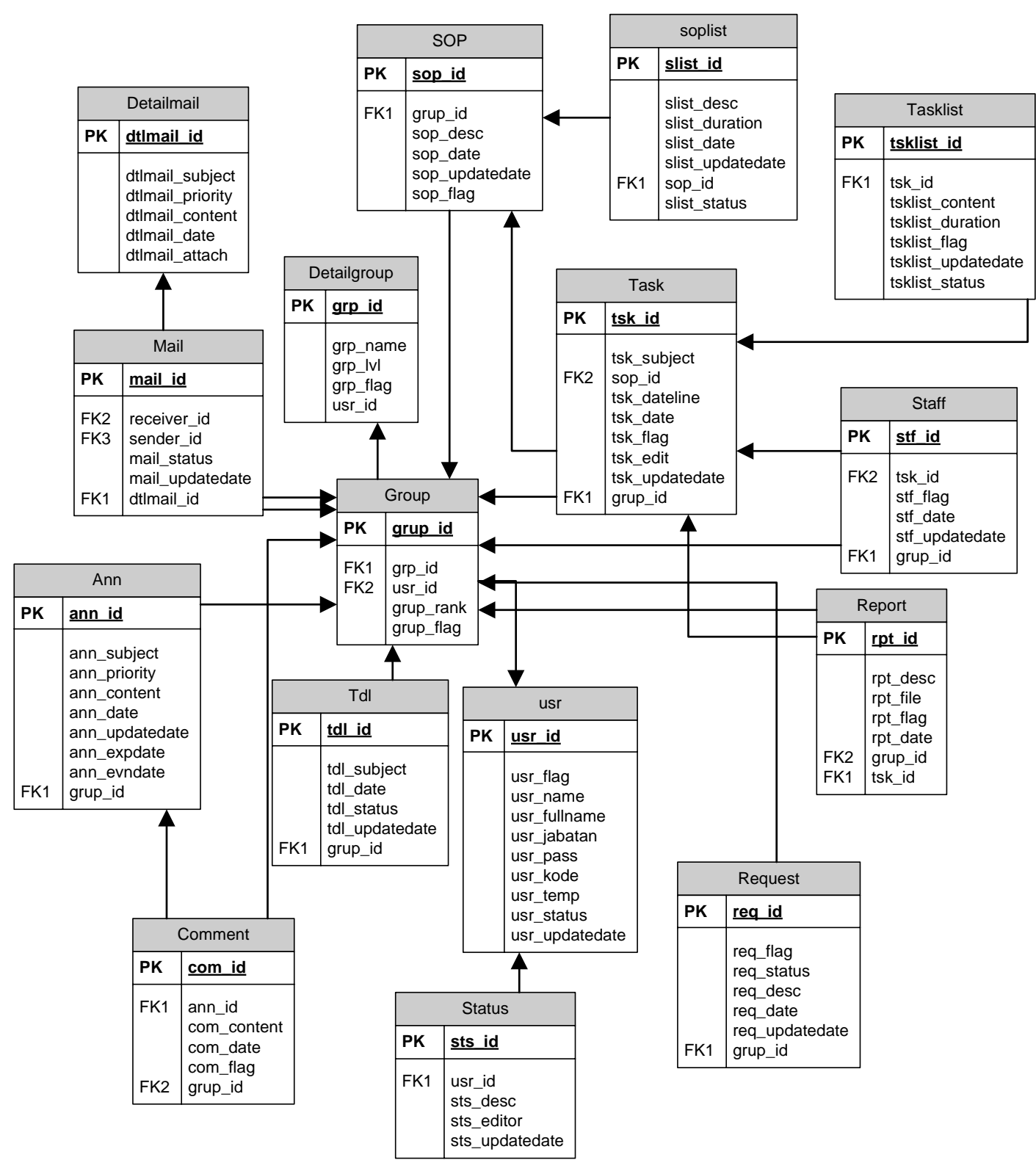

Gambar 5 Entity Relationship Diagram

Sedangkan spesifikasi perangkat lunaknya adalah sistem operasi Linux, PHP minimum versi 4.3.2, Apache minimum versi 1.3, dan MySQL minimum versi 4.0. Untuk client, spesifikasi perangkat keras yang digunakan adalah processor minimum Pentium 4, memori minimum $256 \mathrm{MB}$, ethernet card/modem, mouse, keyboard, dan mionitor. Sedangkan spesifikasi perangkat lunaknya adalah sistem operasi Microsoft Windows XP Professional dan Mozilla Firefox minimum versi 3.0.

\section{Prosedur Evaluasi}

Aplikasi E-board diimplementasikan pada Jurusan Teknik Informatika BINUS UNIVERSITY, yaitu empat orang staf jurusan dan 2 orang staf dari luar jurusan (Software Laboratory Center). Evaluasi aplikasi dilakukan dengan dua cara, yaitu evaluasi terhadap kegunaan aplikasi dan evaluasi terhadap antar muka dari aplikasi. 


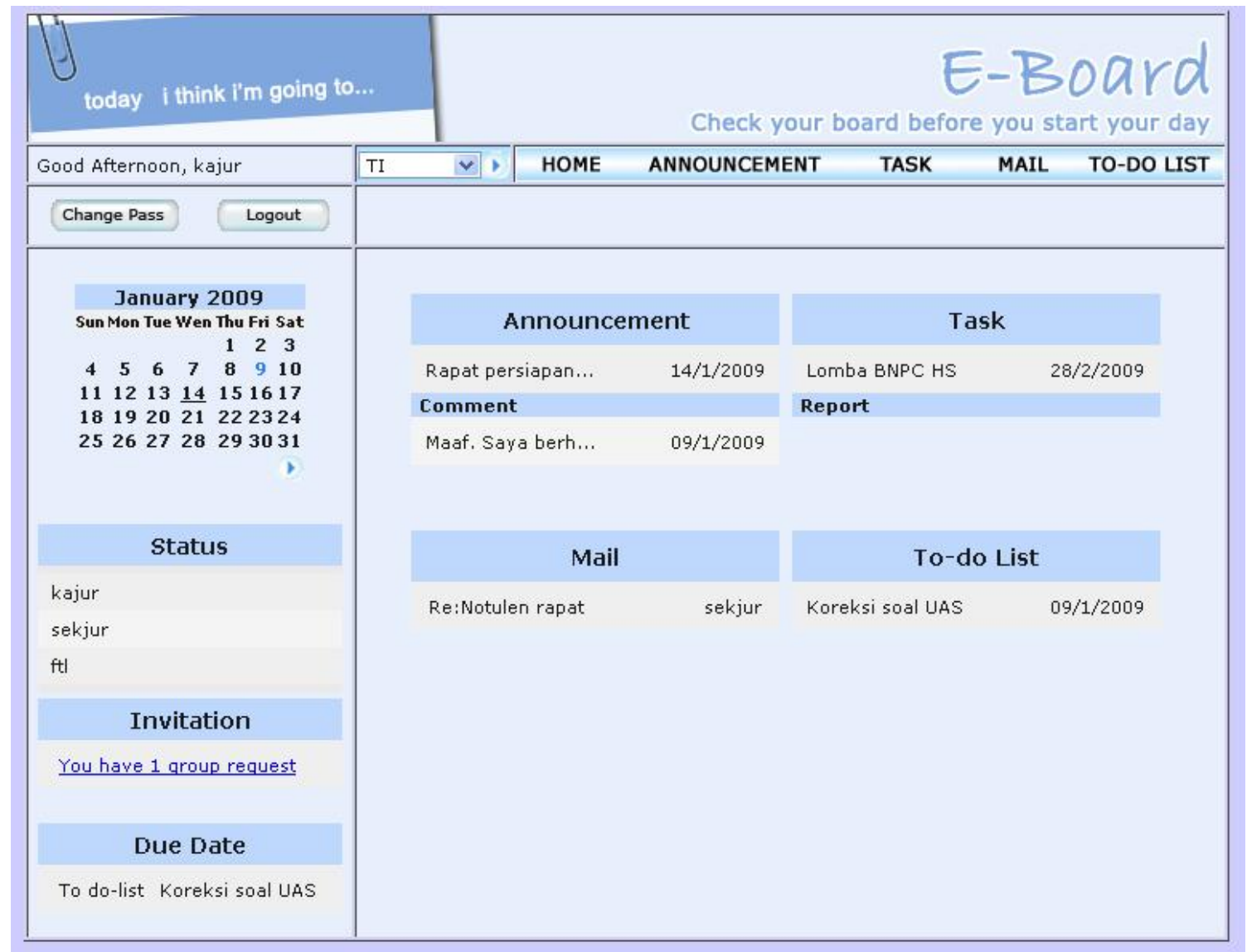

Gambar 6 Halaman home untuk user

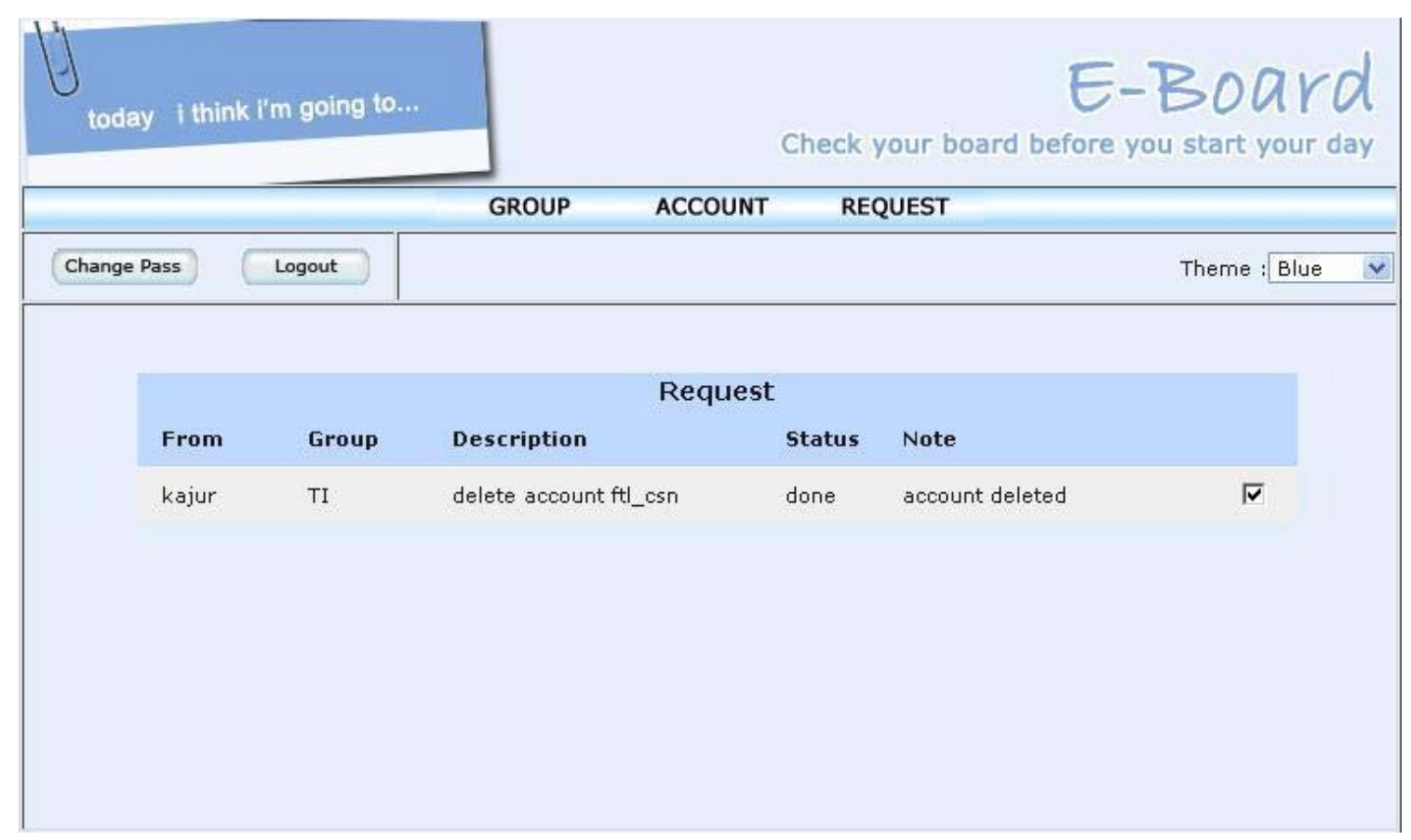

Gambar 7 Halaman utama untuk admin 


\section{Evaluasi Kegunaan Aplikasi}

Untuk mengetahui usability aplikasi dari sudut pandang user, maka dilakukan evaluasi dengan cara wawancara langsung ke user. Setiap responden diberikan lima belas pertanyaan dengan pilihan jawaban sangat setuju, setuju, tidak setuju, dan sangat tidak setuju. Pertanyaan dalam kuisioner difokuskan pada keterjawaban permasalahan pada system sebelumnya, selain itu juga menggunakan panduan lima Faktor Manusia dalam teori IMK untuk pengukuran usability suatu aplikasi. Adapun hasil dari interview tersebut antara lain:

Tabel 1 Data Hasil Evaluasi Terhadap Kegunaan Aplikasi

\begin{tabular}{llcccc}
\hline No. & \multicolumn{1}{c}{ Pertanyaan } & $\begin{array}{c}\text { Sangat } \\
\text { Setuju }\end{array}$ & Setuju & $\begin{array}{c}\text { Tidak } \\
\text { Setuju }\end{array}$ & $\begin{array}{c}\text { Sangat Tidak } \\
\text { Setuju }\end{array}$ \\
\hline 1. & Kemudahan distribusi informasi & $50 \%$ & $50 \%$ & - & - \\
2. & $\begin{array}{l}\text { Ketepatan distribusi informasi (tepat kepada } \\
\text { orang yang dituju) }\end{array}$ & $67 \%$ & $33 \%$ & - & - \\
3. & Integritas informasi & $67 \%$ & $33 \%$ & - & - \\
4. & Kemudahan identifikasi rekan kerja & $67 \%$ & $33 \%$ & - & - \\
5. & Kemudahan koordinasi dengan rekan kerja & $67 \%$ & $33 \%$ & - & - \\
& fungsional & & & & - \\
6. & Kemudahan proses pelaporan kegiatan & $33 \%$ & $67 \%$ & - & - \\
7. & Kemudahan pencarian informasi & $17 \%$ & $83 \%$ & - & - \\
8. & Kedetilan dan struktur informasi & $16 \%$ & $67 \%$ & $17 \%$ & - \\
9. & Pemilihan prioritas pekerjaan & $67 \%$ & $33 \%$ & - & - \\
10. & Kemudahan penggunaan aplikasi & $16 \%$ & $67 \%$ & $17 \%$ & - \\
11. & Kemudahan mempelajari aplikasi & $33 \%$ & $50 \%$ & $17 \%$ & - \\
12. & Kemudahan mengerti aplikasi (pesan kesalahan) & $16 \%$ & $67 \%$ & $17 \%$ & - \\
13. & Kelengkapan fungsi & $17 \%$ & $50 \%$ & $33 \%$ & - \\
14. & Kesesuaian tampilan dan fungsi aplikasi & $16 \%$ & $67 \%$ & $17 \%$ & - \\
15. & Kepuasan terhadap aplikasi & $83 \%$ & $17 \%$ & - & - \\
\hline
\end{tabular}

\section{Evaluasi Terhadap Antar Muka Aplikasi}

Evaluasi ini dilakukan dengan menggunakan panduan delapan aturan pokok (8 Golden Rules of Interface Design), yaitu (1) berusaha untuk konsisten, aplikasi e-Board sudah dapat dikatakan konsisten, hal tersebut dapat dilihat dari pemberian warna dasar, warna tulisan, pemilihan jenis, bentuk dan ukuran huruf, menu yang konsisten pada keseluruhan aplikasi, struktur tampilan layar yang identik; (2) memungkinkan frequent user menggunakan shortcut (jalan pintas), aplikasi e-Board menggunakan shortcut yang berguna untuk user yang sering menggunakan. Sehingga user dapat lebih mudah untuk berinteraksi dengan aplikasi melalui tombol-tombol khusus dan akan mempercepet kinerja user. Penggunaan shortcut pada aplikasi ini dapat ditemukan pada calendar; (3) memberikan umpan balik yang informative, aplikasi e-Board dapat memberikan respon balik dari aksi yang dilakukan oleh user kepada sistem, seperti pesan kesalahan dan pesan sukses ketika berhasil melakukan aksi; (4) merancang dialog untuk menunjukan keadaan akhir, aplikasi e-Board memberikan pesan pada setiap keadaan akhir dari sebuah aksi dari user yang telah berhasil sehingga user dapat melanjutkan proses berikutnya; (5) pencegahan dan penanganan kesalahan yang sederhana, aplikasi e-Board memberikan pencegahan dan penanganan yang sederhana dengan memberikan keterangan pada form sehingga user mengetahui batasan yang ada pada aplikasi; (6) mengizinkan pembalikan aksi yang mudah, aplikasi e-Board mempunyai fungsi yang dapat mengembalikan aksi ke aksi sebelumnya, dapat ditemukan pada saat create sop dan add member; (7) mendukung internal locus of control, aplikasi e-Board memberikan user kebebasan untuk memegang kendali sistem dan 
menghendaki sistem merespon aksinya, dapat ditemukan pada sorting mail dan pemilihan theme; (8) mengurangi beban ingatan jangka pendek user, aplikasi e-Board mempunyai kemampuan mengurangi beban ingatan jangka pendek user. Hal tersebut dapat ditemukan pada pembuatan mail dan task, dimana untuk menentukan user yang dituju cukup dengan memilih dari daftar yang ada.

\section{PENUTUP}

Berdasarkan analisis, perancangan, implementasi, dan evaluasi aplikasi e-Board didapatkan simpulan sebagai berikut. Pertama, aplikasi ini dapat digunakan sebagai bagian dari kebutuhan komunikasi dan informasi dalam sistem kerja sama asinkron tersebar. Kedua, supervisor dapat memberikan penugasan dengan informasi yang terstruktur dan juga dapat memantau tugas yang diberikan. Ketiga, pencarian informasi menjadi lebih mudah dengan adanya pengorganisasian informasi oleh aplikasi. Keempat, pemberian prioritas pada informasi membantu menentukan pekerjaan yang harus diselesaikan terlebih dahulu. Kelima, keberadaan rekan kerja terutama yang tidak berada pada satu ruangan dapat diidentifikasi dengan lebih mudah. Keenam, teknologi AJAX memungkinkan aplikasi web untuk di-update hanya pada bagian tertentu sesuai dengan request, tanpa harus me-reload seluruh halaman web.

Beberapa saran yang dapat diberikan untuk pengembangan selanjutnya dari aplikasi e-Board adalah sebagai berikut. Pertama, penambahan fitur shared workspace dimana memungkinkan dua atau lebih user untuk mengakses, mengedit atau membuat dokumen bersama secara real time untuk mendukung kerjasama tim yang lebih fleksibel. Kedua, penambahan fitur notulen sehingga notulen rapat dapat langsung terhubung dengan fitur penugasan pada aplikasi ini. Ketiga, pengembangan aplikasi menjadi aplikasi desktop. Sehingga pengaksesan informasi dapat dilakukan secara offline. Keempat, pengintegrasian dengan sistem e-mail untuk komunikasi dengan kelompok kerja external.

\section{DAFTAR PUSTAKA}

Garret, J. J. (2005). Ajax: A New Approach to Web Application, from http://www.adaptivepath.com/publications/essays/archives/000385.php

Messerchmitt, D. G. (2000). Understanding Networked Applications: a First Course. Morgan Kaufmann Publishers.

O’Reilly, T. (2005). What Is web 2.0, from http://www.oraillynet.com/pub/a/oreilly/tim/news/2005/09/30/what-is-web-20.html

Shneiderman, B. (2010). Designing the User Interface: Strategies for Effective Human-Computer Interaction (3rd ed.). Addison-Wesley. 